\title{
Teaching Effectiveness of Secondary School Teachers in the District of Purba Medinipur, West Bengal
}

\author{
Umasankar Dash ${ }^{1} \&$ Pranab Barman ${ }^{2}$ \\ '(Research Scholar; Dept. of Education; Sidho-Kanho-Birsha University, Purulia, West Bengal, India) \\ '(Assistant Professor; Dept. of Education; Sidho-Kanho-Birsha University, Purulia, West Bengal, India)
}

\begin{abstract}
Effective Teaching is an art and no easy endeavour. Generally Teaching is delivered by a teacher to enhance the amount of learning of a learner. To make learning more meaningful, understandable and fruitful to a learner, effectiveness of teaching delivered by a teacher is very essential condition. Through the present study an attempt has been made by the investigators to study the level of Teaching Effectiveness of Secondary School Teachers in the district of Purba Medinipur, West Bengal. The investigators have used Descriptive Survey method for the present study. In this study, Teaching Effectiveness of Teachers has been evaluated by their concerned students. The sample consists of 100 Teachers who were working in different Secondary Schools in the district of Purba Medinipur. The Stratified random sampling technique has been used for the selection of sample. The investigators have developed a Scale by themselves to measure the level of Teaching Effectiveness of Teachers on the basis of Likert's five point scale i. e. Strongly Agree, Agree, Neutral, Disagree and Strongly Disagree. For the analysis of data Mean, S.D., t-Test, ANOVA and Graph have been used by the investigators in the present study. The results of the study explore that the Overall level of Teaching Effectiveness of Secondary School Teachers is good in the district of Purba Medinipur. It is also revealed that though there is no significant difference among the Secondary School Teachers regarding their level of Teaching Effectiveness on the basis of Gender, Stream, Training Status and Qualification, but it is found that there is significant difference among the Secondary School Teachers regarding their level of Teaching Effectiveness on the basis of School Location.
\end{abstract}

Keywords: Teaching, Teaching Effectiveness, Secondary Schools, Teachers, Dimensions of Teaching Effectiveness.

\section{INTRODUCTION}

Teacher is the backbone of any nation. The progress and development of a nation largely depends on its teachers' community because of their noble and massive contributions in nation building. They have remarkable contributions in making and shaping each and every person of the society. The quality of education is determined by the quality of teachers (Kareem \& Ravirot, 2014). That's why teachers are considered very essential and indispensible factor of any education system. They are referred to as the people who instruct to provide the teaching learning process. Teachers are the mainstay of the educational system $(\boldsymbol{A f e}, \mathbf{2 0 0 0} \&$ Kiadese, 2011). The academic success or failure of a learner largely depends on this factor of education. That's why Kothari Education Commission (1964-66) has very aptly remarked that "of all the different factors which influence the quality of education and its contribution to nation development, the quality, competence and character of teachers are undoubtedly the most significant".

Actually, it is strongly true that there is a significant relationship between teacher's factors and student's achievement (Olatoye, 2006; Adekola, 2006 \& Kiadese, 2011). There are so many factors which affects students' academic achievement. According to Postlethwaite (2007) students' academic achievement is dependent on Teacher-related Variables, Environment or Family-related Variables and School-related Variables. Among these variables, one of the most vital Teacher-related Variables or factors which contribute immensely to enhance students' academic achievement is 'Teaching Effectiveness'.

\subsection{Teaching Effectiveness: Meaning \& Definitions}

Before going to define Teaching Effectiveness, we have to know clearly what is 'Teaching'. Actually, "Teaching is complex, and great practice takes time, passion, high-quality materials, and tailored feedback designed to help each teacher continuously grow and improve" (Vicki Phillips, 2013). According to Oyedeji (1998) - Teaching is a process of imparting knowledge, skills and attitude in order to bring about a desirable change in learners. The primary goal of teaching is to ensure that meaningful learning occurs (Ogunyemi, 2000). When such kind of teaching took place by a teacher then we called the teaching delivered by the teacher has become effective i.e. effective teaching or teaching effectiveness. 
Teaching Effectiveness is a very important aspect of education because effective teaching helps student learning as well as enhancing the students' academic performance or achievement. It has become even more important as the emphasis on quality in higher education has increased. Effective teaching does not occur by chance by a teacher. Actually "Effective teaching is dependent on the coordination of several components: the objectives, the student, the content, and the teacher" (McKeachie, 1997). That's why Richard Elmore (2009) said that "To improve student learning, you do not change the structure. You change the instructional practices of teachers. The schools that seem to do best are those that have a clear idea of what kind of instructional practice they wish to produce, and then design a structure to go with it".

Tom Kane (2013) also said on this matter that "If we want students to learn more, teachers must become students of their own teaching. They need to see their own teaching in a new light. Public school systems across the country have been re-thinking how they describe instructional excellence and let teachers know when they've achieved it". Therefore, it can be said that teaching is effective when it enables student learning.Good teaching is nothing to do with making things hard. It is nothing to do with frightening students. It is everything to do with benevolence and humility; it always tries to help students feel that a subject can be mastered; it encourages them to try things out for themselves and succeed at something quickly (Ramsden, 1992 \& Weimer, 2009). "Good teaching fosters [a] sense of student control over learning and interest in the subject matter". "Effective teaching refuses to take its effect on students for granted. It sees the relation between teaching and learning as problematic, uncertain and relative. Good teaching is open to change: it involves constantly trying to find out what the effects of instruction are on learning, and modifying the instruction in the light of the evidence collected" (Ramsden, 1992 \& Weimer, 2009).

However, Teaching Effectiveness or Effectiveness of Teaching or Effective Teaching is an established field of study. Many scholars and researchers have tried to define the term 'Teaching Effectiveness' in numerous ways through their study. But it is very difficult to give a precise definition of Teaching Effectiveness. Kullbert (1989) and Baker (1990) have tried to give a definition of Effective Teaching that is "Effective Teaching should stimulate student curiosity and active learning, encourage student analytical, logical, and creative thinking, and increase both their desire and capacity for future learning". Bastick (1995) defines Effective Teaching as maximizing student academic attainment, and teacher and student course satisfaction. He also stated that effective teaching can be measured by using the Three-Ability Framework (3AF) which consists of Technical Skills, Professional Competence and Professional Attitude.

Olatoye (2006) said that Teaching Effectiveness is the extent that student's performance improves after a period of instruction in a manner consistent with the goals of instruction. Omoniyi (2005) asserted that effective teaching is those activities which bring about the most productive and beneficial learning experience for students and promotes their development as learners.

Ogunyemi (2000) argued that effective teaching goes beyond just imparting knowledge but it is a purposeful activity carried out by someone with a specialized knowledge in a skilful way to enhance the cognitive, affective and psychomotor development of a person or group of persons.

Centra (1993) emphasizes on cognitive theory approach to define Teaching Effectiveness. According to him, Effective Teaching is demonstrated when instructors use classroom procedures that are compatible with a student's cognitive characteristics, can organize and present information to promote problem solving and original thinking on issues, and can show that students are able to become more productive thinkers and problem solvers.

Palmer (1998) has defined Teaching Effectiveness in a different angle. According to him, Reduce teaching to intellect and it becomes a cold abstraction; reduce it to emotions, and it becomes narcissistic; reduce it to the spiritual, and it loses its anchor to the world. ... Good teaching cannot be reduced to technique; good teaching comes from the identity and integrity of the teacher.

According to Stringer and Irwing (1998), Teaching Effectiveness could be figured out through the extent that students' performance improves after a period of instruction, in a manner consistent with the objectives of the instruction and in accordance with prior set goal(s). Thus, the effectiveness of teaching can be measured through the changes which have occurred in the students' knowledge (declarative and procedural), their level of motivation, ability to cope with constant changes in life, and effective management of stress after they had been given the instruction. Due to this uniqueness of effective teaching, many post-secondary institutions adopted students' rating of instruction as one measure of instructional effectiveness (d'Apollonia $\boldsymbol{\&}$ Abrami, 1997 and Griffin, 2004).

Evans (2006) argued that Effective Teaching is synonymous with Teaching Effectiveness and has been defined in three basic ways. These include definitions in terms of (i) Teachers' personalities (ii) Teacher-pupil interactions and (iii) Teachers' impact on pupil's behaviour. The presage, process and product aspects of teaching are represented in these definitions very well. The presage and process aspects of teaching bear direct relationship to teachers' personalities and teacher-pupil interactions. Similarly, the product aspect bears direct 
relationship to teacher impact on pupil's behaviour. Evans (2006) also defined that Teaching Effectiveness as a manifestation of knowledge of content, skills in lesson presentation and creating desirable atmosphere for learning. Along teacher-pupil interaction line, Evans (2006) also defined Teaching Effectiveness as a kind of classroom transactions that occur between teachers and students resulting to increase in students' knowledge. This refers to communication skills, use of praises, rewards, motivation, etc during teaching process. Afe (2003) defined Teaching Effectiveness as the type of teaching characterized by the exhibition of intellectual, social and emotional stability, love for children and positive disposition towards the teaching profession and ability to inspire good qualities in students.

\subsection{Factors Contributing to Teaching Effectiveness:}

Oyekan (2000) investigated the attributes of Teaching Effectiveness among the secondary school teachers. Findings revealed that Teaching Effectiveness in classroom practices include; Broad based knowledge of the subject matter, effective use of chalkboard, good language and communication skills; well organized learning environment; formulation of clear objective. According to Ferdinand (2007) effective teaching entails a clearly formulated objective illustrated instruction and effective evaluation technique.

Nonis and Hudson (2004) stated five important dimensions of students' perceptions of Teaching Effectiveness which include rapport, classroom interaction, enthusiasm, clarity and learning. Berk (2005) derived twelve strategies to measure effective teaching which include student ratings, pear ratings, alumni ratings, employer ratings, administrator ratings, self evaluation, student interviews, videos of practice, teaching scholarship, teaching awards, learning outcome measures and teaching portfolios. Miron and Segal (2004) stated that the university student rated their lecturer by their ability to transmit knowledge rather than according to the university's criteria of research and publication. They added that good teacher and effective instruction were used interchangeably although they are not identical.

On the basis of study conducted by eminent scholar Paul Ramsden, Maryellen Weimer (2009) identified six important strategies which make teaching effective. These are Interest and Explanation, Concern and respect for students and student learning, appropriate assessment and feedback, Clear goals and intellectual challenge, Independence, control and active engagement, and Learning from students.

According to Marsh (1987) and Ramsden (1991) Teaching Effectiveness depends on some teacher related characteristics such as empathy, facilitation, personal attention, teacher support, student involvement, negative effect, enthusiasm and rapport and interaction as more conducive to teaching effectiveness. On the other side Harrison et al. (2004) have emphasized on teacher's academic competence, communication competence, professional maturity, presentation, and organization and clarity as indicative of teaching effectiveness. Ansari \& Ansari (2000) have indicated that, the delivery of information, meaningful interaction, feedback and fair treatment etc. are the most responsible factors in Teaching Effectiveness. They suggested that Teaching Effectiveness is a multi-trait and multi-dimensional phenomenon in which many characteristics of the instructor are involved.

In this connection, Els Heijnen-Maathuis (2003) said that, the Classroom Management is an integral part of Effective Teaching, as it helps to prevent behavior problems through improved planning, organizing and managing of classroom activities, better presentation of instructional material and better teacher-student interaction, aiming at maximizing students' involvement and cooperation in learning. Eble (1971) pointed out that there are five components of effective teaching as perceived by the students. They include teacher must use an analytic/synthetic approach, well organized, teacher-group interaction, teacher-individual students interaction and dynamism/enthusiasm manner. Smith and Cranton (1992) contributed a checklist for good teaching by including test prerequisite skills, provides feedback to the teacher, adopts to individual differences, provide feedback to the students, flexible, promotes active student learning, motivates students and clear and wellorganized.

Charlotte Danielson's (1996) book, Enhancing Professional Practice: A Framework for Teaching, outlines measures relating to effective teaching organized into four domains, each with several observable teacher behaviors: Planning and Preparation, The Classroom Environment, Instruction, and Professional Responsibilities.

Robert Marzano's (2007) model of Teaching Effectiveness, The Art and Science of Teaching: A Comprehensive Framework for Effective Instruction, articulates his framework in the form of 10 questions that represent a logical planning sequence for successful instructional design including: establishing learning goals, students interaction with new knowledge, student practice to deepen understanding, engaging students, effective classroom management, effective student teacher relationships, communicating high expectation for students, and effective, standards-based, formative and summative assessment practices which use multiple measures of students' proficiency. Colker (2008) reported that teachers claimed there were four characteristics of an effective teacher which include having a sound knowledge of subject matter, take personal interest in each 
student, establish a caring or loving or warm atmosphere and finally to show enthusiasm with students. Colker (2008) also identified the twelve characteristics of teachers that children believe are integral factors to effective teaching. There are passion, perseverance willingness to take risks, pragmatism, patience, flexibility, respect creativity, authenticity, love of learning, high energy and sense of humour. Check (2006) found out from a study on the teachers that the following traits to be essential for effective teaching: proper dress and grooming, extensive use of examples, employment of humour, effective communication in teaching, valid testing techniques and availability for extra help.

Simon and Boyer $(2010, p .85)$ through their study have identified some important factors or variables that affect Teaching Effectiveness as well as students' achievement to a great extend. They categorized them into four broad dimensions or variables:

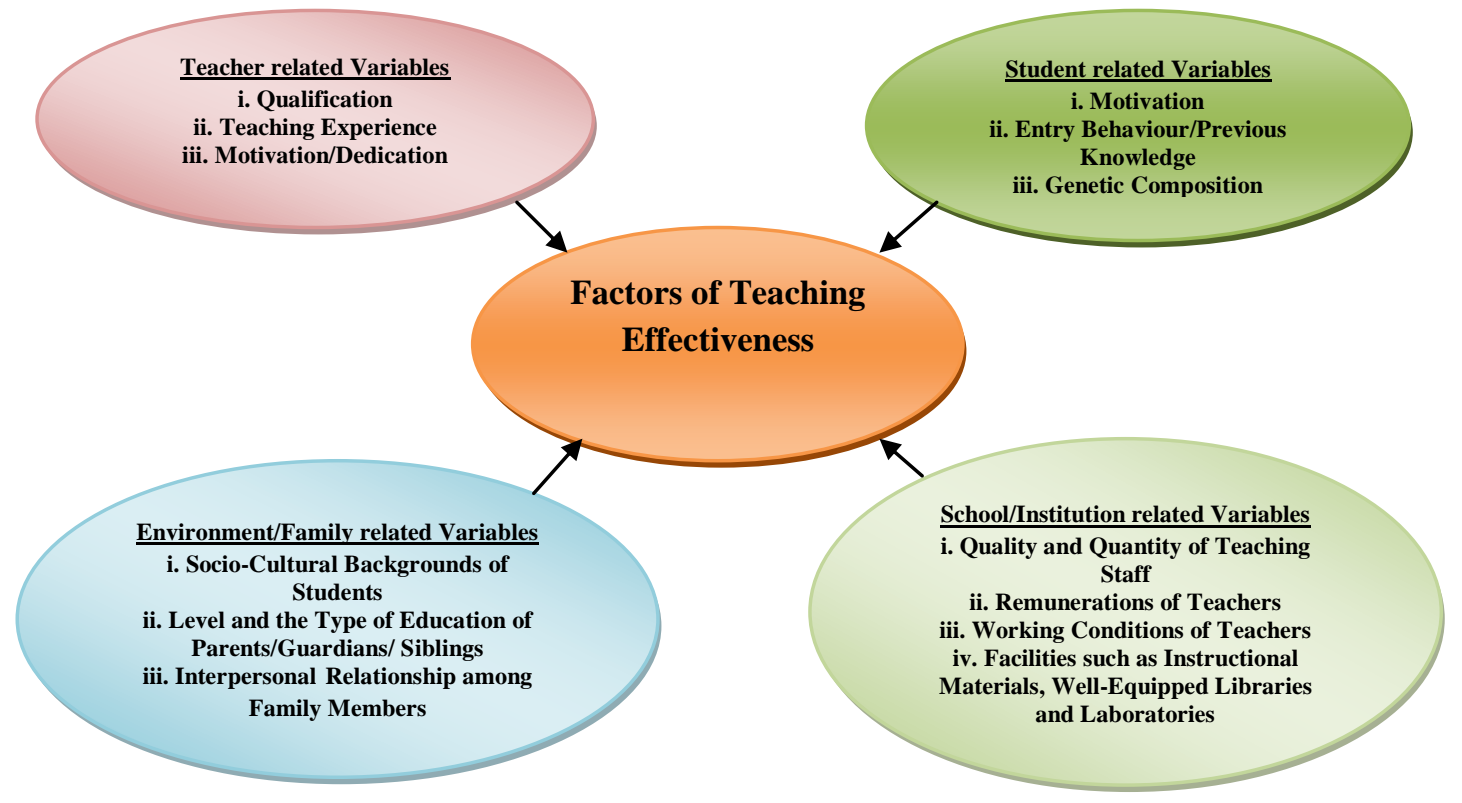

Figure-1: Source: Simon and Boyer (2010, p.85)

\section{REVIEW OF RELATED LITERATURE}

Padmanabaiah (1984) conducted a study on "Job Satisfaction and Teaching Effectiveness of Secondary School Teachers”. He found no significant difference existed between suitably qualified and over qualified teachers with regard to their Teaching Effectiveness. But age and experience of teachers showed that there were great influence existed on their Teaching Effectiveness.

Jayamma (2002) reported that training did not influence the professional success of teachers, but experience and qualifications have a significant influence on the professional success of teachers.

Vijaya Lakshmi (2005) conducted a study on "Teacher Effectiveness and Job Satisfaction of Women Teachers" to find out the effect of locality, management and subject of teaching on teacher effectiveness and job satisfaction. The findings of the study revealed that the locality of school and subject of teaching have no significant impact on teacher effectiveness.

Jones (2005) through his study found out that there was no significant difference between trained and untrained teachers regarding their Teaching Effectiveness in Barbados.

Sharadha and Paremeswaram (2008) in their study on "Teacher Characteristics and Learning in the Classroom", make an attempt to examine the role of some behavioural variations among teachers and their possible implications for effective classroom teaching and learning. The findings of the study revealed that the gender and locality of the institutions had significant impact on the behaviour variations in the level of their Teaching Effectiveness.

Sundara Rao (2009) investigated "Teacher Effectiveness as an Observational Study" by using 90 Teaching Staff through the observational techniques. He found that sex had no significant affiliation with teacher effectiveness scores. It is found that female teachers were more effective that male teachers. It is 
revealed that science teachers were comparatively more effective than the arts teachers. Along with this it is also found that trained teachers were comparatively more effective than the untrained teachers.

Sodhi (2010) has conducted a study on "Teacher Effectiveness of Secondary School Teachers of Punjab in relation to School Organizational Climate". The findings of the study reveal that there were no significant differences in Teacher Effectiveness of secondary school teachers across gender, location, stream and teaching experience groups.

Kiadese (2011) has conducted a study on "An Assessment of the Teaching Effectiveness of Prevocational Subject Teachers in Ogun State, Nigeria”. The findings of the study revealed that majority of the prevocational subject teachers had low Teaching Effectiveness. It is found that there was no significant gender difference in the Teaching Effectiveness of prevocational subject teachers. Besides, it is also found that there was no significant difference in the Teaching Effectiveness of graduate and non graduate prevocational subject teachers.

Malik and Sharma (2013) have conducted a study on "Teaching Effectiveness of Secondary School Teachers in Relation to their Professional commitment”. This study reveals that gender of teachers does not bear any relationship with their Teaching Effectiveness. It also reveals that locality of schools does not influence the Teaching Effectiveness of teachers.

Tyagi (2013) conducted a study on "Teaching Effectiveness of Secondary School Teachers in Relation to their Demographic Characteristics" to find out demographic characteristics-wise perception of Secondary School Teachers with references to their teaching effectiveness. The findings of the study revealed that Qualification, Stream, Teaching Experience and Locality of the School had a significant impact on the Teaching Effectiveness of secondary school teachers.

Onyekuru and Ibegbunam (2013) conducted a study on "Teaching Effectiveness of Secondary School Teachers in Emohua Local Government Area of Rivers State, Nigeria” to find out the Teaching Effectiveness of secondary school teachers in Emohua Local Government Area. The results of the study reveal that the Teaching Effectiveness of secondary school teachers in Emohua Local Government Area was below average and therefore low. It is found that gender had no significant influence on Teaching Effectiveness of secondary school teachers. But it is found that Teaching Experience and Qualification had a significant influence on Teaching Effectiveness of secondary school teachers in Emohua Local Government Area of Rivers State, Nigeria.

Eleri (2013) has conducted a study on "Teaching Effectiveness in Elements of Special Education in NCE-Awarding Institutions in Nigerian:-Influence of Teacher Qualification and Experience". The findings of the study showed that various aspects of classroom teaching were ineffective (means range from 2.08 to 2.63). Lecturers' qualification and experience did not significantly affect their teaching effectiveness.

Pachaiyappan and Ushalaya Raj (2014) have conducted a study on "Evaluating the Teacher Effectiveness of Secondary and Higher Secondary School Teachers". The findings of the study reveal that the male and female school teachers did not differ significantly in their teacher effectiveness. The study also reveals that there was a significant difference in teacher effectiveness among the school teachers with respect to locale, arts and science stream, secondary and higher secondary level, teaching experience and type of school management.

Chowdhury (2014) has conducted a study on "Effectiveness of Secondary School Teachers in relation to their Gender, Age, Experience and Qualification". The study revealed that majority of the teachers both male and female had average level of effectiveness in their teaching-learning process. The study demonstrates that there was no significant difference in the effectiveness of secondary school teachers in terms of their gender, age, experience and qualification.

Kothawade (2014) has conducted a study on "Correlative Study of Teaching Effectiveness \& Job Satisfaction of Higher Secondary School Teachers". The results of the study reveal that Teaching Effectiveness of higher secondary school teachers of Dhulia district is $44.04 \%$. The significant difference found in teaching effectiveness in male \& female teachers of higher secondary schools of Dhulia district. Besides, no significant difference found in teaching effectiveness in Arts \& Science faculty's teachers of higher secondary schools of Dhulia district.

From the aforesaid discussion of the previous literature, it is clear that none of studies have been carried out by the any researcher in the context of Purba Medinipur district of West Bengal. That's why the present investigators have chosen this topic to know the levels of Teaching Effectiveness of Teachers who are engaged to teach the students in various secondary schools in the district of Purba Medinipur, West Bengal.

III. OBJECTIVES OF THE STUDY

The researchers have conducted their study on the basis of the following objectives: 
1. To find out the level of Teaching Effectiveness of Secondary School Teachers in the District of Purba Medinipur.

2. To find out the difference between Male and Female School Teachers regarding their Teaching Effectiveness at Secondary level.

3. To find out the difference between Arts and Science School Teachers regarding their Teaching Effectiveness at Secondary level.

4. To find out the difference between Rural and Urban School Teachers regarding their Teaching Effectiveness at Secondary level.

5. To find out the difference between Trained and Untrained School Teachers regarding their Teaching Effectiveness at Secondary level.

6. To find out the difference between High Qualified and Low Qualified School Teachers regarding their Teaching Effectiveness at Secondary level.

7. To find out the difference among the School Teachers regarding their Teaching Effectiveness on the basis of their Teaching Experience at Secondary Level.

\section{HYPOTHESES OF THE STUDY}

$H_{\boldsymbol{O}_{1}}$ There would not have high level of Teaching Effectiveness of Secondary School Teachers in the District of Purba Medinipur.

$\boldsymbol{H O}_{2}$ : There is no significant difference between Male and Female School Teachers regarding their Teaching Effectiveness at Secondary level.

$\boldsymbol{H O}_{3}$ : There is no significant difference between Arts and Science School Teachers regarding their Teaching Effectiveness at Secondary level.

$\boldsymbol{H O}_{4}$ : There is no significant difference between Rural and Urban School Teachers regarding their Teaching Effectiveness at Secondary level.

$\boldsymbol{H O}_{5}$ : There is no significant difference between Trained and Untrained School Teachers regarding their Teaching Effectiveness at Secondary level.

$H_{0}$. There is no significant difference between High Qualified and Low Qualified School Teachers regarding their Teaching Effectiveness at Secondary level.

$\boldsymbol{H O}_{7}$. There is no significance difference among the School Teachers regarding their Teaching Effectiveness on the basis of their Teaching Experience at Secondary Level.

\section{OPERATIONAL DEFINITION OF THE TERMS}

\subsection{Teaching Effectiveness:}

The term 'Teaching Effectiveness' means the collections of characteristics, competencies and behaviors of teachers at all educational levels that enable students to reach desired outcomes. Here in this study the researchers have used the term 'Teaching Effectiveness' to mean that the effectiveness of teaching delivered by the Teachers in the following dimensions-(i) Subject Matter Knowledge, (ii) Preparation and Organization (iii) Presentation Style, (iv) Classroom Management, (v) Motivational Strategy, (vi) Effective Communication, (vii) Student-Teacher Interaction, (viii) Evaluation and Feedback, (ix) Informal Academic Support and (x) Personal Attribute.

\subsection{Secondary School:}

Here in this study the term 'Secondary School' means that those type of schools which are engaged to impart the secondary education (class VIII to X) to the students under the West Bengal Board of Secondary Education (WBBSE).

\subsection{Teacher:}

Here in this study the term 'Teacher' means that those persons who are engaged to teach the students at secondary level schools under the West Bengal Board of Secondary Education (WBBSE). In this study the following types of teachers have been categorized: Male Teacher, Female Teacher, Urban School Teacher (who are working in various Urban secondary schools), Rural School Teacher (who are working in various Rural secondary schools), Trained Teacher (who have a degree of Teacher Training Course, like-B.Ed., B.P.Ed., M.P.Ed.), Untrained Teacher (who have no degree of Teacher Training Course, like-B.Ed., B.P.Ed., M.P.Ed.), High Qualified Teacher (who are possessed with only M.A/M.Sc. and M.A/M.Sc. with B.Ed.), Low Qualified Teacher (who are possessed with only B.A/B.Sc and B.A/B.Sc with B.Ed. or B.P.Ed.). 


\section{METHODOLOGY OF THE STUDY}

\subsection{Method of the Study:}

The present study is descriptive type in nature. The researchers have used the descriptive type survey method in the present study. Therefore, naturally the investigators have used different tools, techniques, strategies and method of descriptive survey research to collect, analyze and interpret the data.

\subsection{Population of the Study:}

All the Teachers of Secondary Schools under the West Bengal Board of Secondary Education (WBBSE) of the district of Purba Medinipur have been treated as population for the present study.

\subsection{Sample of the Study:}

The researcher has selected only 100 Teachers among the all Teachers from the five selected Secondary Schools which are situated in the district of Purba Medinipur as a sample for the present study.

\subsection{Sampling Technique:}

The Stratified Random Sampling technique has been applied in the selection of the sample.

\subsection{Tool of the Study:}

The investigators have used a self made Teaching Effectiveness Scale as a tool for collecting the data in the present study. The Scale consists of 55 items with the combination of positive (33) and negative (22) items. The Scale has been constructed on the basis of 10 (Ten) important dimensions of Teaching Effectiveness, namely-Subject Mastery, Preparation \& Organization, Presentation Style, Classroom Management, Effective Communication, Motivational Strategy, Student-Teacher Interaction, Evaluation \& Feedback, Informal Academic Support and Personal Attribute. The Scale has been constructed followed by Likert's five point scale i.e. Strongly Agree (S.A), Agree (A), Neutral (N), Disagree (D) and Strongly Disagree (S.D). The test-retest method is employed to measure the reliability of the Teaching Effectiveness Scale and the value of reliability is to be 0.89 .

\subsection{Techniques of Data Analysis:}

The present investigators have used Mean, S.D. t-Test, ANOVA and Graph for analyzing the data.

\subsection{Data Collection Procedure and Scoring:}

As per previous planning the tool was administered upon the samples of the five selected secondary schools in the district of Purba Medinipur. The authority and the concerned students of each school were informed well in advance by the researcher for the purpose of collection of data. After getting the permission from the school authority, the researcher went to the concerned class and the students were asked by the researcher that whom teachers have taught them. Then the researcher has selected the name of the teachers on the basis of students' opinion and those names of the teachers were distributed among the selected number of students randomly by the Lottery method. Hence, one particular teacher has been evaluated by the one particular student whom he/she (teacher) has taught. After that the required numbers of Questionnaires were distributed among the selected students and they were instructed to read the all items of the Questionnaire and give their opinion against the all items carefully. After the completion of the answering of the Questionnaire by all the students, the filled in copies of the Questionnaire were collected from them. Finally, all the students and authority of the school were thanked by the researcher for their cooperation that they extended in collecting the data for the present study.

After collecting the all Questionnaires (100) from the five selected schools, the researcher has calculated the total score on a Questionnaire by computing the score against the each and every item. In computing the score of each items of the Questionnaire, the researcher has used a preselected method. In case of positive item, direct scoring method that was 5-4-3-2-1 has been used and in case of negative items, reverse scoring method that was 1-2-3-4-5 has been used by the researcher in computing the score of each and every items of the Questionnaire. This total process of computing of the Questionnaire has been done by the researcher very carefully and sensitively.

\subsection{Techniques of Measuring the Level of Teaching Effectiveness:}

After all the items are scored, the scores of all the 55 items are added to obtain the total score of an individual Sample on the Teaching Effectiveness Scale. The range of the total score is 55-275 as the Scale is constructed by 55 items on the basis of Likert's five point Scale. Therefore, the Level of Teaching Effectiveness 
is considered from Score of the answers and is classified into 5 levels as per the Best's Criteria (1977) as follows:

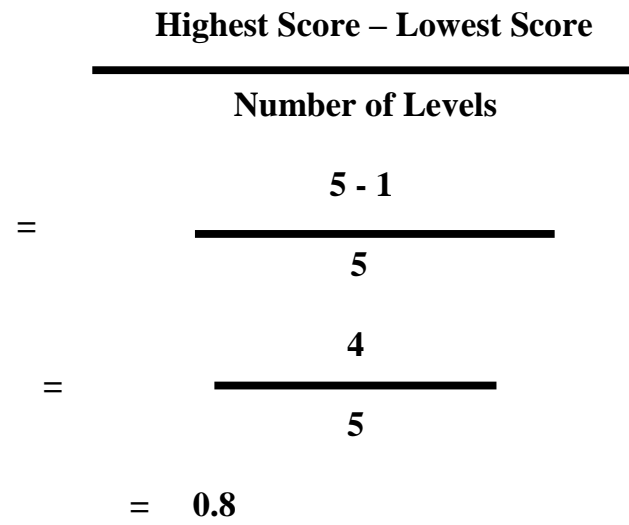

Table No-1: Criteria for Understanding the Means of the Level of Teaching Effectiveness

\begin{tabular}{|c|c|}
\hline Range of Scores & Level of Teaching Effectiveness \\
\hline $1.00-1.80$ & Very Poor/Very Low Effective \\
\hline $1.81-2.60$ & Poor/Low Effective \\
\hline $2.61-3.40$ & Moderately Effective \\
\hline $3.41-4.20$ & Good/Highly Effective \\
\hline $4.21-5.00$ & Very Good/Very Highly Effective \\
\hline
\end{tabular}

VII. RESULTS AND INTERPRETATION

$H O_{1:}$ There would not have high level of Teaching Effectiveness of Secondary School Teachers in the District of Purba Medinipur.

Table No-2

Summary of the Overall Level of Teaching Effectiveness of Secondary School Teachers of the District of Purba Medinipur, West Bengal

\begin{tabular}{|c|l|c|c|c|c|c|}
\hline $\begin{array}{c}\text { Sl. } \\
\text { No }\end{array}$ & \multicolumn{1}{|c|}{ Name of the Dimensions } & $\begin{array}{c}\text { No. } \\
\text { of } \\
\text { Items }\end{array}$ & $\begin{array}{c}\text { Number of } \\
\text { Teachers }\end{array}$ & $\mathbf{X}$ & S.D & Meaning \\
\hline 1 & Subject Matter Knowledge & 5 & 100 & 4.02 & 1.46 & Good \\
\hline 2 & Preparation and Organization & 5 & 100 & 3.85 & 1.50 & Good \\
\hline 3 & Presentation Style & 12 & 100 & 3.95 & 1.28 & Good \\
\hline 4 & Classroom Management & 5 & 100 & 3.72 & 1.35 & Good \\
\hline 5 & Motivational Strategy & 3 & 100 & 4.18 & 1.12 & Good \\
\hline 6 & Effective Communication & 3 & 100 & 3.97 & 1.46 & Good \\
\hline 7 & Student Teacher Interaction & 5 & 100 & 4.08 & 1.28 & Good \\
\hline 8 & Evaluation and Feed Back & 7 & 100 & 4.02 & 1.28 & Good \\
\hline 9 & Informal Academic Support & 4 & 100 & 3.67 & 1.23 & Good \\
\hline 10 & Personal Attribute & 6 & 100 & 3.75 & 1.39 & Good \\
\hline \multicolumn{2}{|l}{ Overall Teaching Effectiveness } & $\mathbf{5 5}$ & $\mathbf{1 0 0}$ & $\mathbf{3 . 9 2}$ & $\mathbf{1 . 3 3}$ & Good \\
\hline
\end{tabular}

Figure No-2

Graphical Representation of Mean Score obtained by the Teachers of Purba Medinipur District on the Entire Dimension of Teaching Effectiveness 


\section{Mean Scores on Teaching Effectiveness}
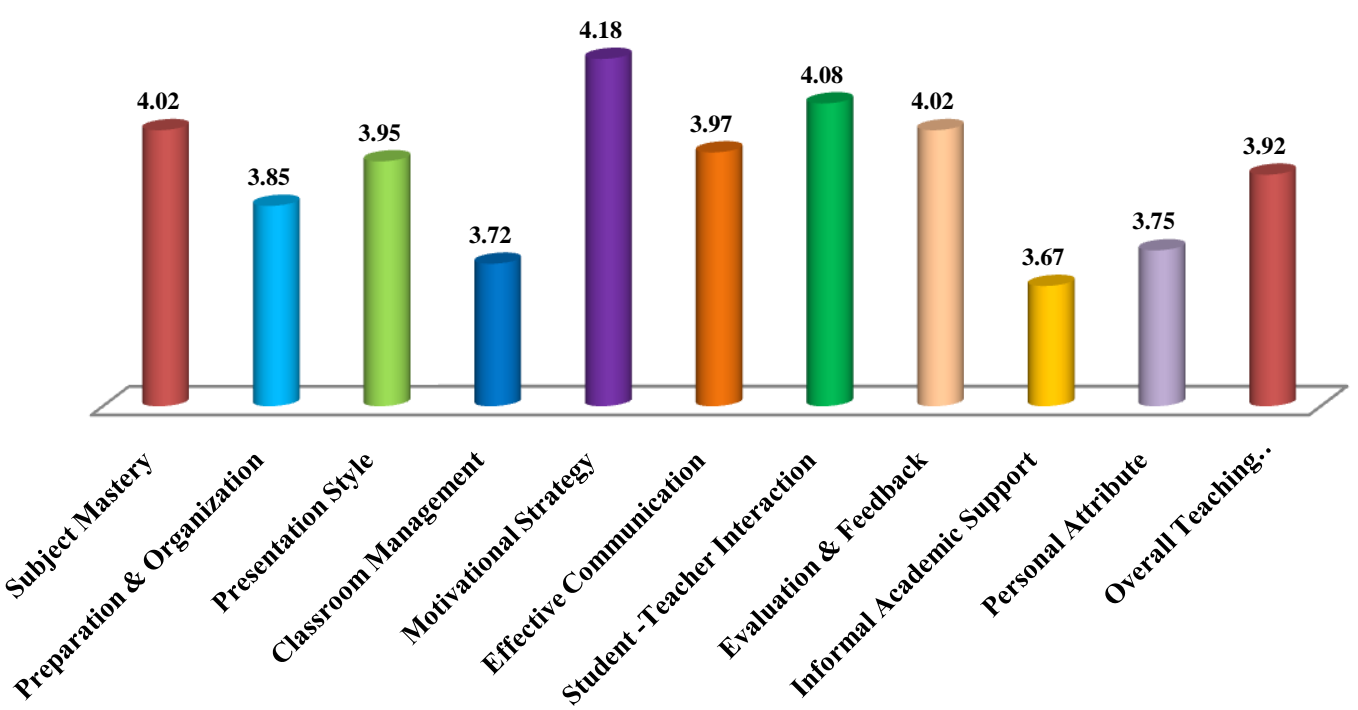

Note: 1.00-1.80=Very Poor; 1.81-2.60=Poor; 2.61-3.40=Moderate; 3.41-4.20=Good and 4.21-5.00=Very Good.

The table no-2 and figure no-2 indicate that the overall level of Teaching Effectiveness of Secondary School Teachers of the district of Purba Medinipur is at Good Level with the Mean Score of 3.92 and S.D of 1.33. The above table and figure show that the level of Teaching Effectiveness on the dimensions of Subject Matter Knowledge; Preparation and Organization; Presentation Style; Classroom Management; Motivational Strategy; Effective Communication; Student-Teacher Interaction; Evaluation and Feedback; Informal Academic Support and Personal Attribute of the Secondary School Teachers of the district of Purba Medinipur is at Good Level with the Mean Score of 4.02, 3.85, 3.95, 3.72, 4.18, 3.97, 4.08, 4.02, 3.67 \& 3.75 respectively and S.D of 1.46, $1.50,1.28,1.35,1.12,1.46,1.28,1.28,1.23 \& 1.39$ respectively. Therefore, the hull hypothesis $\left(\boldsymbol{H O}_{I}\right)$ is rejected and it can be said that the overall level of Teaching Effectiveness of the Teachers of the district of Purba Medinipur is Good at Secondary Level. Or it can be said in another angle that the teaching delivered by the teachers is highly effective at secondary level in the district of Purba Medinipur, West Bengal.

Table No-3: Shows the Number, Mean, S.D., and t-value of different groups of Teachers on their Teaching Effectiveness

\begin{tabular}{|c|c|c|c|c|c|c|c|}
\hline Groups/Variables & $\mathbf{N}$ & Mean & S.D & $\begin{array}{c}\text { Mean } \\
\text { Difference }\end{array}$ & $\mathbf{S}_{\mathbf{E D}}$ & df & t-Value \\
\hline Male Teachers & 81 & 219.04 & 29.20 & \multirow{2}{*}{5.38} & \multirow{2}{*}{7.60} & \multirow{2}{*}{98} & \multirow{2}{*}{$0.70 @$} \\
\hline Female Teachers & 19 & 224.42 & 32.43 & & & & \\
\hline Arts Teachers & 52 & 218.12 & 28.19 & \multirow{2}{*}{4.05} & \multirow{2}{*}{5.97} & \multirow{2}{*}{98} & \multirow{2}{*}{$0.67 @$} \\
\hline Science Teachers & 48 & 222.17 & 31.58 & & & & \\
\hline Rural School Teachers & 58 & 226.66 & 28.55 & \multirow{2}{*}{15.70} & \multirow{2}{*}{5.85} & \multirow{2}{*}{98} & \multirow{2}{*}{$2.68 * *$} \\
\hline Urban School Teachers & 42 & 210.95 & 29.28 & & & & \\
\hline Trained Teachers & 89 & 218.02 & 29.92 & \multirow{2}{*}{18.52} & \multirow{2}{*}{9.37} & \multirow{2}{*}{98} & \multirow{2}{*}{$1.97 @$} \\
\hline Untrained Teachers & 11 & 236.55 & 23.34 & & & & \\
\hline High Qualified Teachers & 78 & 220.37 & 31.15 & \multirow{2}{*}{1.41} & \multirow{2}{*}{7.21} & \multirow{2}{*}{98} & \multirow{2}{*}{$0.19 @$} \\
\hline Low Qualified Teachers & 22 & 218.95 & 24.70 & & & & \\
\hline
\end{tabular}

*Significant at 0.05,** Significant at 0.01 and @ Not Significant (Table Value of 't' against df (98) at 0.05 level $=1.98 \&$ at 0.01 level $=2.63$ ) 
Teaching Effectiveness of Secondary School Teachers in the District of Purba

Table No-4: Shows the Number, Mean and S.D. of Teachers on Teaching Effectiveness on the basis of their Teaching Experience

\begin{tabular}{|c|c|c|c|}
\hline Teaching Experience & N & MEAN & S.D \\
\hline Below 5 Years & 13 & 217.15 & 22.64 \\
\hline Between 5 to 10 Years & 22 & 227.95 & 34.98 \\
\hline Above 10 Years & 65 & 217.97 & 29.05 \\
\hline Total & $\mathbf{1 0 0}$ & $\mathbf{2 2 0 . 0 6}$ & $\mathbf{2 9 . 7 5}$ \\
\hline
\end{tabular}

Table No-5: Shows the difference among the Secondary School Teachers regarding their Teaching Effectiveness on the basis of their Teaching Experience

\begin{tabular}{|c|c|c|c|c|}
\hline Sources of Variance & Sum of Squares & df & $\begin{array}{c}\text { Mean } \\
\text { Square }\end{array}$ & F-ratio \\
\hline Between Groups & 1765.055 & 2 & 882.527 & $0.99 @$ \\
\hline Within Groups & 85840.585 & 97 & 884.954 & \\
\hline Total & 87605.640 & 99 & \multicolumn{2}{|c}{} \\
\cline { 1 - 3 }
\end{tabular}

*Significant at $0.05, * *$ Significant at 0.01 and @ Not Significant [Table value of ' $F$ ' with the df of $97 / 2$ at $0.05=3.09$ \& at $0.01=4.82]$

\section{Testing of $\mathrm{HO}_{2}$ and Interpretation:}

From the table no-3, it is observed that the calculated ' $t$ '-value $(0.70)$ is less than the table value at 0.05 level of significance (1.98 at 0.05 level of significance). Therefore, the result is not significant and it indicates that there is no statistically significant difference between Male and Female school teachers regarding their Teaching Effectiveness at Secondary level. Hence, the null hypothesis is accepted. But on the basis of their obtained Mean Scores, it can be said that the level of Teaching Effectiveness of Female teachers is comparatively better than the Male teachers in the district of Purba Medinipur, West Bengal.

\section{Testing of $\mathrm{HO}_{3}$ and Interpretation:}

From the table no-3, it is observed that the calculated ' $t$ '-value $(0.67)$ is less than the table value at 0.05 level of significance (1.98 at 0.05 level of significance). Therefore, the result is not significant and it indicates that there is no statistically significant difference between Arts and Science school teachers regarding their Teaching Effectiveness at Secondary level. Hence, the null hypothesis is accepted. But on the basis of their obtained Mean Scores, it can be said that the level of Teaching Effectiveness of Science teachers is comparatively better than the Arts teachers in the district of Purba Medinipur, West Bengal.

\section{Testing of $\mathrm{HO}_{4}$ and Interpretation:}

From the table no-3, it is observed that the calculated ' $t$ '-value (2.68) is greater than the table value at the both level of significance (1.98 at $0.05 \& 2.63$ at 0.01 level of significance). Therefore, the result is significant and it indicates that there is statistically significant difference between Rural and Urban school teachers regarding their Teaching Effectiveness at Secondary level. Hence, the null hypothesis is rejected. And on the basis of their obtained Mean Scores, it can be said that the level of Teaching Effectiveness of Rural School teachers is comparatively better than the Urban School teachers in the district of Purba Medinipur, West Bengal.

\section{Testing of $\mathrm{HO}_{5}$ and Interpretation:}

From the table no-3, it is observed that the calculated ' $t$ '-value (1.97) is less than the table value at 0.05 level of significance (1.98 at 0.05 level of significance). Therefore, the result is not significant and it indicates that there is no statistically significant difference between Trained and Untrained school teachers regarding their Teaching Effectiveness at Secondary level. Hence, the null hypothesis is accepted. But on the basis of their obtained Mean Scores, it can be said that the level of Teaching Effectiveness of Untrained School teachers is comparatively better than the Trained School teachers in the district of Purba Medinipur, West Bengal.

\section{Testing of $\mathrm{HO}_{6}$ and Interpretation:}

From the table no-3, it is observed that the calculated ' $t$ '-value $(0.19)$ is less than the table value at 0.05 level of significance (1.98 at 0.05 level of significance). Therefore, the result is not significant and it indicates that there is no statistically significant difference between High and Low Qualified school teachers regarding their Teaching Effectiveness at Secondary level. Hence, the null hypothesis is accepted. But on the basis of their 
obtained Mean Scores, it can be said that the level of Teaching Effectiveness of High Qualified School teachers is comparatively better than the Low Qualified School teachers in the district of Purba Medinipur, West Bengal.

\section{Testing of $\mathrm{HO}_{7}$ and Interpretation:}

From the table no-4 \& 5, it is observed that the calculated F-ratio is 0.99 which is less than the table value at the both level of significance ( 3.09 at $0.05 \& 4.82$ at 0.01 level of significance). Therefore, the result is not significant and it indicates that there is no statistically significant difference among the School Teachers regarding their level of Teaching Effectiveness on the basis of their Teaching Experience at Secondary Level. Hence, the null hypothesis is accepted. But on the basis of their obtained Mean Scores, it can be said that the level of Teaching Effectiveness of teachers with the teaching experience of between 5-10 years is comparatively better than the other group of teachers in the district of Purba Medinipur, West Bengal.

\section{MAJOR FINDINGS AND DISCUSSION OF THE RESULTS}

In the present study it is found that there exists Good level of Teaching Effectiveness among the Teachers who are working in various secondary schools in the district of Purba Medinipur, West Bengal. This finding negates the findings of Kiadese (2011) that majority of the prevocational subject teachers had low Teaching Effectiveness. This finding also negates the findings of Onyekuru and Ibegbunam (2013) that Teaching Effectiveness of secondary school teachers in Emohua Local Government Area was below average and therefore low. This finding also negates the findings of Eleri (2013); Chowdhury (2014); and Kothawade (2014).

The second finding of the study is that there is no statistically significant difference between Male and Female school teachers regarding their Teaching Effectiveness at Secondary level. It means that gender has no significant influence on Teaching Effectiveness of Secondary School Teachers in the district of Purba Medinipur. This finding is supported by the studies of Chacko (1981); Akpan (1996); Sundara Rao (2009); Sodhi (2010); Kiadese (2011); Malik \& Sharma (2013); Onyekuru \& Ibegbunam (2013); Pachaiyappan \& Ushalaya Raj (2014); and Chowdhury (2014). All the studies showed that gender has no significant influence on Teaching Effectiveness of Teachers. Besides, this finding of the study has contradicted the findings of the studies conducted by Sharadha \& Paremeswaram (2008) and Kothawade (2014). They revealed that gender has a significant influence on Teaching Effectiveness of Teachers.

The third finding of the study is that there is no statistically significant difference between Arts and Science school teachers regarding their Teaching Effectiveness at Secondary level. It means that Stream or Subject of Teaching has no significant influence on Teaching Effectiveness of Secondary School Teachers in the district of Purba Medinipur. This finding is supported by the studies of Sharadha \& Paremeswaram (2008), Tyagi (2013; and Pachaiyappan \& Ushalaya Raj (2014). They found that Stream or Subject of Teaching has no significant impact on Teaching Effectiveness of Teachers. But, this finding of the study has contradicted the findings of the studies conducted by Vijaya Lakshmi (2005); Sodhi (2010); and Malik \& Sharma (2013). They revealed that Stream or Subject of Teaching has a significant influence on Teaching Effectiveness of Teachers.

The fourth finding of the study is that there is statistically significant difference between Rural and Urban school teachers regarding their Teaching Effectiveness at Secondary level. It means that Locality of School has a significant influence on Teaching Effectiveness of Secondary School Teachers in the district of Purba Medinipur. This finding is supported by the studies of Vijaya Lakshmi (2005); Sodhi (2010); and Kothawade (2014). They found that Locality of School has a significant impact on Teaching Effectiveness of Teachers. But, this finding of the study has contradicted the findings of the studies conducted by Sundara Rao (2009); Tyagi (2013); and Pachaiyappan \& Ushalaya Raj (2014). They revealed that Locality of School has no significant influence on Teaching Effectiveness of Teachers.

The fifth finding of the study is that there is no statistically significant difference between Trained and Untrained school teachers regarding their Teaching Effectiveness at Secondary level. It means that Training Status has no significant influence on Teaching Effectiveness of Secondary School Teachers in the district of Purba Medinipur. This finding is supported by the studies of Jayamma (2002); and Jones (2005). They found that Training Status has no significant impact on Teaching Effectiveness of Teachers. But, this finding of the study has contradicted the findings of the study conducted by Sundara Rao (2009). He revealed that Training Status has a significant influence on Teaching Effectiveness of Teachers.

The sixth finding of the study is that there is no statistically significant difference between High and Low Qualified school teachers regarding their Teaching Effectiveness at Secondary level. It means that Qualification has no significant influence on Teaching Effectiveness of Secondary School Teachers in the district of Purba Medinipur. This finding is supported by the studies of Padmanabaiah (1984); Kiadese (2011); and Chowdhury (2014). They found that Qualification has no significant impact on Teaching Effectiveness of 
Teachers. But, this finding of the study has contradicted the findings of the study conducted by Jayamma (2002); Tyagi (2013); and Onyekuru \& Ibegbunam (2013). They revealed that Qualification has a significant influence on Teaching Effectiveness of Teachers.

The seventh or last finding of the study is that there is no statistically significant difference among the School Teachers regarding their level of Teaching Effectiveness on the basis of their Teaching Experience at Secondary Level. It means that Teaching Experience has no significant influence on Teaching Effectiveness of Secondary School Teachers in the district of Purba Medinipur. This finding is supported by the studies of Sodhi (2010); and Chowdhury (2014). They found that Teaching Experience has no significant impact on Teaching Effectiveness of Teachers. But, this finding of the study has contradicted the findings of the study conducted by Padmanabaiah (1984); Jayamma (2002); Tyagi (2013); Onyekuru \& Ibegbunam (2013); and Pachaiyappan \& Ushalaya Raj (2014). They revealed that Teaching Experience has a significant influence on Teaching Effectiveness of Teachers.

\section{CONCLUSION}

From the above findings the following conclusions are drawn:

i. The level of Teaching Effectiveness of Teachers working in various secondary schools in the district of Purba Medinipur, West Bengal is good. It means that Teaching delivered by the secondary school Teachers is Highly Effective in the district of Purba Medinipur, West Bengal.

ii. It is concluded that there is no statistically significant difference between Male and Female school teachers regarding their Teaching Effectiveness at Secondary level. But on the basis of their obtained Mean Scores, it can be said that the level of Teaching Effectiveness of Female teachers is comparatively better than the Male teachers in the district of Purba Medinipur, West Bengal.

iii. It is concluded that there is no statistically significant difference between Arts and Science school teachers regarding their Teaching Effectiveness at Secondary level. But on the basis of their obtained Mean Scores, it can be said that the level of Teaching Effectiveness of Science teachers is comparatively better than the Arts teachers in the district of Purba Medinipur, West Bengal.

iv. It is concluded that there is statistically significant difference between Rural and Urban school teachers regarding their Teaching Effectiveness at Secondary level. And on the basis of their obtained Mean Scores, it can be said that the level of Teaching Effectiveness of Rural School teachers is comparatively better than the Urban School teachers in the district of Purba Medinipur, West Bengal.

v. It is concluded that there is no statistically significant difference between Trained and Untrained school teachers regarding their Teaching Effectiveness at Secondary level. But on the basis of their obtained Mean Scores, it can be said that the level of Teaching Effectiveness of Untrained School teachers is comparatively better than the Trained School teachers in the district of Purba Medinipur, West Bengal.

vi. It is concluded that there is no statistically significant difference between High and Low Qualified school teachers regarding their Teaching Effectiveness at Secondary level. But on the basis of their obtained Mean Scores, it can be said that the level of Teaching Effectiveness of High Qualified School teachers is comparatively better than the Low Qualified School teachers in the district of Purba Medinipur, West Bengal.

vii. It is concluded that there is no statistically significant difference among the School Teachers regarding their level of Teaching Effectiveness on the basis of their Teaching Experience at Secondary Level. But on the basis of their obtained Mean Scores, it can be said that the level of Teaching Effectiveness of teachers with the teaching experience of between 5-10 years is comparatively better than the other group of teachers in the district of Purba Medinipur, West Bengal.

Lastly, it can be said that as teachers play a very important role in making the future citizens of nation then it is very necessary to improve the quality of Teaching of teachers. Because of the quality of education as well as the future of our nation largely depends on the quality of Teachers and his/her quality teaching. It is very interestingly found through the present study that the untrained school teachers are comparatively high effective than the trained school teachers in the Purba Medinipur district. Besides that, it is also found that the rural school teachers are comparatively high effective than the urban school teachers. It is a quite exceptional matter. Generally it is expected that trained and urban school teachers would be better in teaching than the untrained and rural school teachers respectively. Therefore, it is a very considerable matter of teaching learning aspect of school education in the district of Purba Medinipur, West Bengal. 


\section{REFERENCES}

[1] Adekola, B.O. (2006). Influence of Teachers' Qualification, Age, and Gender on Effective Teaching of English Language. Journal of Educational Focus, 6, 97-99.

[2] Afe, J.O. (2002). Reflection on Becoming a Teacher and the Challenges of Teacher Education. Inaugural Lecture, Series 64, University of Benin.

[3] Afe, J. O. (2003). Teacher Effectiveness: Imperative for Implementing Universal Basic Education in Nigeria. Journal of Nigeria Academy of Education, 1(1), 1-9.

[4] Akpan, A. A. (1996). Teacher effectiveness as a determinant of students' performance in mathematics: A theoretical review. Journal of Research Information in Education. 1(1) 89-99.

[5] Ansari, Mahroof A. \& Ansari, Mustapha A. Z. A. (2000). Development of a Measure of Teacher Effectiveness for IIUM. Intellectual Discourse, 8 (2), 199-220.

[6] Ariffin, W. N. N. B. (2010). Effective Teaching: Perception TESL Teacher Trainees on Teaching Preparation in ESL Classroom. Unpublished Dissertation Work, University Technology Malaysia.

[7] Barry, Robert A. (2010). Teaching Effectiveness and Why it matters. Marylhurst University.

[8] Bastick, T. (1995). 3AF: The Three-Ability Framework for Assessment in Tertiary Education. Paper presented at the 8th International Conference on Assessing Quality in Higher Education, Finland.

[9] Berk, R.A. (2005). Survey of 12 Strategies to Measure Teaching Effectiveness. International Journal of Teaching and Learning in Higher Education, 17(1), 48-62.

[10] Best, J.W. (1977). Research in Education, Eaglewood Cliffs, New Jersey, Prentice Hall.

[11] Bill and Melinda Gates Foundation (2013). Ensuring Fair and Reliable Measures of Effective Teaching, Culminating Findings from the MET Project's Three-Year Study.

[12] Calaguas, Glenn. M. (2013). Teacher Effectiveness Scale in Higher Education: Development and Psychometric Properties. International Journal of Research Studies in Education, Volume 2, Number 2, 3-20.

[13] Centra, J.A. (1993). Reflective Faculty Evaluation: Enhancing Teaching and Determining Faculty Effectiveness. San Francisco: Jossey-Bass.

[14] Chacko, I. (1981). Learning outcomes in secondary mathematics as related to teachers' and students characteristics. Unpublished Ph.D. Thesis, University of Ibadan.

[15] Check, R.C. (2006). Professional Persons in Public Organizations. Educational Administration Quarterly, Vol.8, No.3, 1-11.

[16] Chowdhury, S. R. (2014). Effectiveness of Secondary School Teachers in relation to their Gender, Age, Experience and Qualification. The Clarion-International Multidisciplinary Journal, Volume : 3, Issue : 1, 141-148.

[17] Colker, L.J. (2008). Twelve Characteristics of Effective Early Childhood Teachers. Journal of the National Association for the Education of Young Children, 63(3), 96-106.

[18] Danielson, C. (1996). Enhancing Professional Practice: A Framework for Teaching. Alexandria: ASCD.

[19] d'Apollonia, S., \& Abrami, P. C. (1997). Navigating Student Rating of Instruction. American Psychologist, 52(11), 1198-1208.

[20] Eble, K.E. (1971). The Recognition and Evaluation of Teaching. Salt Lake City.

[21] Eleri, N. O.E. (2013). Teaching Effectiveness in Elements of Special Education in NCE-Awarding Institutions in Nigerian:-Influence of Teacher Qualification and Experience". IOSR Journal of Research \& Method in Education (IOSR-JRME), Volume 2, Issue 2, 07-16.

[22] Elmore, R., \& Wong, H. (2009). Teachers are the Greatest Assets. Teachers Net Gazette.

[23] Els Heijnen-Maathuis, Regional Education Advisor, Save the Children Sweden. Effective Teaching and Classroom Management is about Whole Child and Whole School Development for Knowledge, Skills and Human Values.

[24] Evans, E. D. (2006). Transition to Teaching. New York. Holt, Rinehart and Winston.

[25] Ferdinand, J. B. (2007). Teachers' Effectiveness and Internal Efficiency in Primary Education. Res. Curr. Stud., 2(1), $2-6$.

[26] Harrison, P. D., \& Douglas, D. K. (2004). The Relative Merits of Different Types of Overall Evaluations of Teaching Effectiveness. Research in Higher Education, 45(3), 311-323.

[27] Ibrahim, M. (2012). A Psychometric Evaluation of Two Teaching Effectiveness Scales. Journal of Sustainable Development, Vol. 5, No. 7, 91-103.

[28] Jayamma, L. (2002). Teaching Aptitude Test, The Psycho-Center, T-22, Green Park, New Delhi.

[29] John, T.P. (1975). A Description of Teaching Effectiveness as Measured by Student Ratings. Journal of Educational Measurement, 12(1), 49-54.

[30] Jones, G. (2005). A Study of Trained and Untrained Teachers' Teaching Skills. Journal of Education and Psychology, Vol. 52, No.1, p.121.

[31] Kareem, J., and Ravirot, B. (2014). A Study on the Self-Concept of Teachers Working in Government, Aided and Unaided Colleges in Bangalore. The IUP Journal of Organizational Behavior, Vol. XIII, No. 1, 61-70.

[32] Kiadese, A. L. (2011). An Assessment of the Teaching Effectiveness of Prevocational Subjects Teachers in Ogun State, Nigeria. International Journal of Vocational and Technical Education, Vol. 3(1), 5-8.

[33] Kothawade, P. L. (2014). Correlative Study of Teaching Effectiveness \& Job Satisfaction of Higher Secondary School Teachers. Indian Journal of Applied Research, Vol. 4, Issue. 7, 116-118.

[34] Kumar, R. R., \& Khadir, F. (2013). A Study on Teaching Effectiveness of Self-Financing Engineering College Teachers in Kerala. International Journal of Asian Social Science, 3(1), 1-9.

[35] Malik, U., \& Sharma, D. K. (2013). Teaching Effectiveness of Secondary School Teachers in Relation to their Professional commitment. International Educational E-Journal, (Quarterly), Volume-II, Issue-IV, 148-154. 
[36] Marsh, H. W. (1987). Students' Evaluation of University Teaching, Research Findings, Methodological Issues, and Directions for Future Research. International Journal of Educational Research, 11, 253-388.

[37] Marzano, R. (2007). The Art and Science of Teaching: A Comprehensive Framework for Effective Instruction. Alexandria: ASCD.

[38] McKeachie, W. J. (1997). Student Ratings: the Validity of Use. American Psychologist, 52 (11), 1218-1225.

[39] Miron, M., \& Segal, E. (1978). The Good University Teacher as Perceived by the Students. Journal of Higher Education, 7(1), 27-34.

[40] Mohidin, R., Jaidi, J., Sang, L. T., and Osman, Z. (2009). Effective Teaching Methods and Lecturer Characteristics a Study on Accounting Students at University Malaysia Sabah (UMS). European Journal of Social Sciences, Volume 8, Number 1. 21-29.

[41] Nonis, S.A., and Hudson, G.I. (2004). Measuring Student Perception of Teaching Effectiveness [WWW] www.sbaer.uca.edu/research/1988/SMA/98sMA064.txt.

[42] Olatoye R.A. (2006). Science Teacher Effectiveness as a Predict Students Performance in the Senior Secondary School Certificate Examination. Journal of Educational Studies, 6, 104-110.

[43] Onyekuru, B. U., \& Ibegbunam, J. O. (2013). Teaching Effectiveness of Secondary School Teachers in Emohua Local Government Area of Rivers State, Nigeria. European Scientific Journal, Vol.9, No.28, 212-226.

[44] Pachaiyappan1, P., \& Ushalaya Raj, D. (2014). Evaluating the Teacher Effectiveness of Secondary and Higher Secondary School Teachers. IOSR Journal of Research \& Method in Education (IOSR-JRME), Volume 4, Issue 1, Ver. V, 52-56.

[45] Padmanabaiah, S. (1984). Job Satisfaction and Teaching Effectiveness of Secondary School Teachers. Unpublished Ph. D. Dissertation, Venkateswara University, Tirupati.

[46] Palmer, P. J. (1998). The Courage to Teach: Exploring the Inner Landscape of a Teacher's Life. San Francisco: Jossey-Bass.

[47] Postlethwaite, T. N. (2007). Evaluating Teacher Competence through the Use of Performance Assessment Task: An Overview. Journal of Personnel Evaluation in Education, 5(1), 121-132.

[48] Ramsden, P. (1991). A Performance Indicator of Teaching Quality in Higher Education: The Course Experience Questionnaire. Studies in Higher Education, 16, 127-150.

[49] Ramsden, P. (1992). Learning to Teach in Higher Education. New York: Routledge.

[50] Reese, Cynthia E. (2009). Effective Teaching in Clinical Simulation: Development of the Student Perception of Effective Teaching in Clinical Simulation Scale. Unpublished Ph.D Thesis, School of Nursing, Indiana University, Indiana.

[51] Report of the Kothari Education Commission (1964-66). Ministry of Education, Government of India. New Delhi.

[52] Sharadha, D.G., and Parameswaram, E.G. (2008). Teacher Characteristics and Learning in the Classroom, Edutracks, Vol.11, No.3, p.18.

[53] Simon, O. I., \& Boyer, T. L. (2010). Teaching Effectiveness: From the Perspectives of Educators. New York: Holt, Rinehart and Winston.

[54] Singh, A.K. (2009). Tests, Measurements and Research Methods in Behavioural Sciences. Bharati Bhawan, New Delhi.

[55] Smith, R.A., \& Cranton, P.A. (1992). Students' Perceptions of Teaching Skills and Overall Effectiveness Across Instructional Settings. Journal of Research in Higher Education, 33(6), 747-764.

[56] Sodhi, B. (2010). Teacher Effectiveness of Secondary School Teachers of Punjab in relation to School Organizational Climate. Unpublished Ph.D Thesis, Punjabi University, Indian ETD Repository @ INFLIBNET.

[57] Stringer, M., \& Irwing, P. (1998). Students' Evaluations of Teaching Effectiveness: a Structural Equation Modeling. British Journal of Educational Psychology, 68, 409-426.

[58] Sundara Rao, G. (2009). Teacher Perception of their Effectiveness as Teacher. Experiments in Education, Vol. 28, No. 2, p. 13.

[59] Tyagi, S. (2013). Teaching Effectiveness of Secondary School Teachers in Relation to their Demographic Characteristics. International Journal of Engineering and Innovative Technology (IJEIT), Volume 3, Issue 1, 288295.

[60] Vijaya Lakshmi, A. (2005). Teacher Effectiveness and Job Satisfaction of Women Teachers. Edutracks, Vol.4, No.7, 7-9.

[61] Weimer, M. (2009). Effective Teaching Strategies: Six Keys to Classroom Excellence. Faculty Focus-Higher Education Teaching Strategies from Magna Publications. 